Published in final edited form as:

Antivir Ther. 2011 ; 16(3): 329-337. doi:10.3851/IMP1746.

\title{
Haemoglobin and anaemia in the SMART study
}

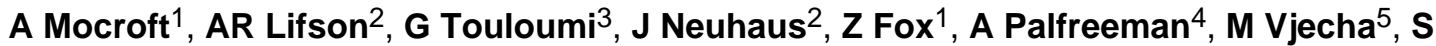 \\ Hodder $^{6}$, S De Wit ${ }^{7}$, JD Lundgren ${ }^{8,9}$, and AN Phillips ${ }^{1}$ for the INSIGHT SMART study group \\ 1 University College Medical School, London, UK \\ 2University of Minnesota, Minnesota, USA \\ ${ }^{3}$ Athens University Medical School, Athens, Greece \\ ${ }^{4}$ Medical Research Council Clinical Trials Unit, London, UK \\ ${ }^{5}$ Veterans Affair Medical Centre, Washington, USA \\ ${ }^{6}$ New Jersey medical School, New Jersey USA \\ ${ }^{7}$ St Pierre Hospital, Brussels, Belgium \\ ${ }^{8}$ Copenhagen HIV Programme, Copenhagen, Denmark \\ ${ }^{9}$ Centre for Viral Disease KMA, Rigshospitalet, Copenhagen, Denmark
}

\section{Abstract}

Background-Data from randomized trials on the development of anaemia after interruption of therapy is not well described.

Methods-2248 patients from the SMART study were included. We used Cox proportional hazards models to investigate development of new ( $₫ 2 \mathrm{mg} / \mathrm{dl}$ for females, $\unlhd 4 \mathrm{mg} / \mathrm{dl}$ for males) or worsening ( $\$ 8 \mathrm{mg} / \mathrm{dl}$ if anaemic at randomization) anaemia and poisson regression analyses to explore the relationship between anaemia and the development of AIDS, death or non-AIDS events.

Results-759 patients developed new or worsening anaemia; 420/1106 (38.0\%) in the drug conservation (DC) arm and 339/1127 (30.1\%) in the virologic suppression (VS) arm; $\mathrm{p}<0.0001$. At 4 months after randomization, patients in the DC arm had a significantly increased risk of developing new or worsening anaemia (adjusted relative hazard 1.56, 95\% CI 1.28-1.89).

Currently anaemic patients had an increased incidence of AIDS (adjusted IRR 2.31; 95\% CI 1.34$3.98)$, death (2.19; 95\% CI 1.23-3.87) and non-AIDS events (2.98; 95\% CI 2.01-4.40) compared to non-anaemic patients.

Conclusions-Patients who interrupted cART had a higher risk of new or worsening anaemia. Anaemic patients had a higher incidence of AIDS, non-AIDS defining events or deaths, possibly due to deteriorating health and subclinical disease.

\section{Keywords}

Anaemia; treatment interruption; haemoglobin; AIDS; death; non-AIDS events

\footnotetext{
Address for correspondence Dr A Mocroft, Research Department of Infection and Population Health, University College London Medical School, Royal Free Campus, Rowland Hill St, London NW3 2PF, Tel: 0207830 2239, Fax: 0207794 1224, a.mocroft@ucl.ac.uk.

* Please see appendix for the INSIGHT SMART Study Group

Conflict of Interest

None reported
} 


\section{Introduction}

Anaemia occurs in a substantial proportion of HIV-infected persons and is associated with considerable mortality and morbidity (1-8). There is less information about whether anaemia is a predictor of events traditionally not thought to be related to HIV, such as cardiovascular disease, chronic kidney disease and cancer, where anaemia is a risk factor in non HIVinfected persons(9-12). Preliminary evidence suggests that anaemia plays a role in fatal and non-fatal non-AIDS events in HIV-infected persons(13). The causes of anemia in HIVinfected persons are multifactorial, including use of treatment such as zidovudine or trimethoprim-sulfamethoxazole (TMP-SMX;(14-16)), nutritional deficiencies(1;17), increased haemolysis(18-20) or HIV infection itself.

One of many effects of combination antiretroviral therapy (cART), in addition to decreasing the rates of progression to AIDS and death, is a positive impact on haemoglobin levels as patients who start treatment tend to experience increases in haemoglobin levels and are less likely to develop anaemia(21;22). The Strategies for Management of Antiretroviral therapy (SMART) trial found that interruption of antiretroviral therapy led to an increase in AIDS, mortality and non-AIDS events(23). This gives rise to the question of whether interruption of treatment is independently associated with decreases in haemoglobin and increases in the number of patients with anaemia. This is one of the first studies, to our knowledge, which is able to assess changes in haempglobin in patients randomized to stop treatment.

The aims of this study were therefore to investigate changes in haemoglobin and development of new or worsening anaemia in the SMART study and to determine the relationship between anaemia and AIDS, non-AIDS events and death.

\section{SMART Study Participants and Treatment Protocol}

Between January 2002 and January 2006, 5,472 HIV-infected participants were enrolled in SMART by 318 sites in 33 countries. Participants were eligible if they had a CD4+ count $>350$ cells $/ \mathrm{mm}^{3}$ and were willing to initiate, modify or stop ART as per study guidelines(23). SMART participants were randomized to one of two ART strategies. ART was used uninterrupted in the viral suppression (VS) group to maximize viral suppression. The drug conservation (DC) strategy entailed episodic use of ART for periods defined by CD4+ count thresholds. ART was stopped (or deferred) until the CD4+ count dropped to $<250$ cells $/ \mathrm{mm}^{3}$, at which time ART was to be (re-initiated and continued until the CD4+ count rose to $>350$ cells $/ \mathrm{mm}^{3}$. ART was then stopped and resumed again when the CD4+ count was $<250$ cells $/ \mathrm{mm}^{3}$. During periods of ART use, the goal was to achieve maximal viral suppression. On January 11, 2006, investigators and participants were notified of a safety risk in the DC group, enrolment was stopped, and participants in the DC group were advised to restart ART(23). Patient follow-up continued for a further 18 months and ended July 11, 2007(24).

The trial protocol was modified on 19 July 2006; a range of laboratory data was collected retrospectively for all patients where available and prospectively for patients alive and under follow-up at that date. As it was not possible to retrospectively collect data on all patients, sites with limited data collected on participants who have died or been lost to follow-up were excluded from analyses of the retrospectively collected data (defined as $<20 \%$ of dead / lost to follow-up participants), as were sites with $<80 \%$ completeness of the measurements of interest at randomization. This decision to remove entire sites based on summary characteristics of data from the site, rather than removing individual patients based on patient characteristics was taken a priori. 


\section{Statistical Methods}

Haemoglobin in the SMART study was retrospectively collected at randomization, month 1, 2, 4, $68,10,12$ and every 4 months thereafter. Anaemia was defined as haemoglobin level $\unlhd 2 \mathrm{mg} / \mathrm{dl}$ for females, $\unlhd 4 \mathrm{mg} / \mathrm{dl}$ for males; due to small numbers of patients with severe anaemia ( $\$ 8 \mathrm{mg} / \mathrm{dl}$ for either males or females)(8;25); anaemia and severe anaemia were grouped together where appropriate. New or worsening anaemia was defined as the development of anaemia in patients without anaemia at randomization or development of severe anaemia in patients with anaemia at randomization. Kaplan-Meier estimation and Cox proportional hazards models were used to investigate factors associated with the first occurrence of new or worsening anaemia. Patient follow-up began at randomization to SMART and ended at new or worsening anaemia or last haemoglobin measurement, thus analyses did not take account of restarting treatment in the DC arm unless otherwise specified. Separate models included fixed and time-updated markers, including CD4 count, viral load, whether the patient was on or off treatment, on or off zidovudine (on treatment variable), development of a new AIDS or non-AIDS defining event etc. SMART did not specifically collect data on use of TMP-SMX, although use of Pneumocystis jiroveji pneumonia (PCP) prophylaxis was collected and adjusted for in models as an indicator of use of TMP-SMX. Demographic factors, such as age, gender, race, smoking status etc, were investigated in univariate models, together with laboratory (CD4, viral load) and treatment (for example, use of zidovudine, PCP prophylaxis, whether the patient was on antiretroviral therapy at randomization) and forward selection with $\mathrm{p}<0.2$ as entry criterion was used to select the final model. The proportional hazards assumption was not valid over follow-up $(\mathrm{p}=0.0005)$. As a consequence, follow-up was stratified into the first 4 months following randomization (this provided the best fitting model and corresponded to follow-up occurring at month 4) and after this time and a separate model was fitted within each period; the proportional hazards assumption was then valid within both periods $(\mathrm{p}>0.05)$.

Poisson regression was used to investigate the relationship between the development of new or worsening anaemia and clinical events; using both fixed (ie anaemia at randomization) and time-updated (ie currently anaemic) values. Clinical events considered were AIDS, death and non-AIDS events (cardiovascular, renal, liver or malignancy, excluding skin cancer(26)). Patient follow-up accrued from randomization until the first AIDS event, death or non-AIDS event respectively, or to last visit for those without an event. There was no evidence that the relationship between new or worsening anaemia and any of the clinical endpoints differed in the DC arm compared to the VS arm ( $p>0.15$, all tests for interaction) and hence they were combined.

All analyses were performed using SAS (Statistical Analysis Software, Cary NC, USA), version 9.1 .

\section{Results}

Of 5472 patients randomized to SMART, 2248 (41.1\%) were from sites with >80\% complete data collected retrospectively and could be included in this analysis. Excluded patients were equally likely to have been randomized to the DC arm (1608 of 3224, 49.9\%, $\mathrm{p}=0.77)$, but were significantly less likely to be of Black race $(\mathrm{p}=0.0013)$, antiretroviral naïve $(\mathrm{p}=0.0007)$ and randomized earlier $(\mathrm{p}<0.0001)$. Compared to North America, excluded patients were more likely to be from any other region and to have a higher viral load at randomization (both $\mathrm{p}<0.0001$ ). Excluded patients were more likely to have died $(\mathrm{p}=0.044)$, marginally significantly more likely to develop AIDS ( $\mathrm{p}=0.076$ ), but equally likely to have developed a non-AIDS event $(\mathrm{p}=0.21)$. The characteristics of the 2248 included patients are shown in Table 1, stratified by the presence of anaemia at randomization; only 3 anaemic patients had severe anaemia at randomisation. The median haemoglobin at randomization 
for those without anaemia was $14.8 \mathrm{mg} / \mathrm{dl}$ (range $12.1-24.2 \mathrm{mg} / \mathrm{dl}$ ) and in those with anaemia was $12.9 \mathrm{mg} / \mathrm{dl}$ (range $5.1-14.0 \mathrm{mg} / \mathrm{dl}$ ). Only 23 patients were taking PCP prophylaxis at randomization, 15 patients without anaemia $(0.9 \%)$ and 8 patients with anaemia $(1.3 \%, \mathrm{p}=0.43)$.

The median number of haemoglobin measurements during follow-up per patients was 11 (interquartile range [IQR] 9-13) and median time between consecutive haemoglobin measurements was 2.3 months (IQR 1.6-3.7). Figure 1 presents a descriptive and cross sectional analyses showing the proportion of patients with new or worsening anaemia and with a $10 \%$ drop in haemoglobin since randomization at various time-points since randomisation; patients in the DC arm are censored at restarting antiretroviral therapy. There was no difference in the proportion of patients with anaemia at randomisation $(p=0.36)$, but at the 1 month time-point, there was a significantly higher proportion with anaemia in the VS arm $(\mathrm{p}=0.0024)$. In the cross sectional analysis, at 4 months after randomization, $29.2 \%$ of the patients in the DC arm had anaemia at this time-point compared to $28.7 \%$ in the VS $\operatorname{arm}(\mathrm{p}=0.80)$ while $6.9 \%$ in the DC arm had experienced a $10 \%$ drop in haemoglobin compared to $5.0 \%$ in the VS arm $(\mathrm{p}=0.070)$.

\section{Time to development of new or worsening anaemia}

Of the 2248 patients, 3 patients had severe anaemia at randomization and 12 patients had no further haemoglobin measurements. Of 2233 remaining patients, 759 developed new or worsening anaemia during follow-up; 420 of 1106 (38.0\%) in the DC arm (of whom 11 had worsening anaemia) and 339 of $1127(30.1 \%$ ) in the VS arm (of whom 5 had worsening anaemia); $<<0.0001$. Kaplan-Meier probabilities of developing new or worsening anaemia at 12 months after randomisation were $30.0 \%$ in the DC arm (95\% CI 26.9-32.4\%) and 24.5\% in the VS arm (95\% CI 22.0-27.1\%). In the first 4 months following randomization (Table 2 ), there was no difference in the risk of new or worsening anaemia when comparing the DC to the VS arm (adjusted relative hazard [RH] 1.02, 95\% CI 0.82-1.25, p=0.88). After the initial 4 months, patients in the DC arm had a significantly increased risk of new or worsening anaemia (adjusted RH 1.56, 95\% CI 1.28-1.89, p<0.0001). Of 614 patients with anaemia or severe anaemia at randomization and at least one follow-up measurement, 217 of $294(73.8 \%)$ resolved their anaemia in the DC arm compared to 241 of $320(75.3 \%)$ in the VS arm ( $\mathrm{p}=0.71)$. There were no differences between the DC or VS arms in the relative hazard of resolution of anaemia before $(p=0.52)$ or after adjustment $(p=0.47)$.

After the initial 4 months, patients with a higher current CD4 cell count had a lower risk of new or worsening anaemia (RH 0.89 per $100 / \mathrm{mm}^{3}$ increase, $95 \%$ CI $0.84-0.93$, p <0.0001) and those in the DC arm had a significantly higher risk compared to those in the VS arm (RH 1.45, 95\% CI 1.09-1.92, $\mathrm{p}=0.0010)$. There was a significant interaction between treatment arm and current use of zidovudine $(\mathrm{p}=0.016)$. After adjustment, patients in the DC arm currently taking zidovudine (i.e., patients who started or restarted zidovudine after randomization to the DC arm) had a 2-fold increased risk of new or worsening anaemia compared to those not currently taking zidovudine (RH 2.20, 95\% CI 1.37-3.54, p=0.0012). In the VS arm, there was no increased risk in patients currently taking zidovudine compared to patients not currently taking zidovudine (RH 1.07, 95\% CI 0.78-1.48, p=0.67).

New or worsening anaemia was also defined more rigorously to assess the sensitivity of our findings to small changes in haemoglobin. The same definition as above was used, but patients were additionally required to have $\geq 10 \%$ decline in haemoglobin. Using this more stringent definition, 262 patients in the DC arm had new or worsening anaemia $(23.7 \%)$ compared to 207 in the VS arm (18.4\%). After the initial 4 months, compared to the VS arm, patients in the DC arm had a significantly increased risk of new or worsening anaemia (adjusted RH 1.43, 95\% CI 1.15-1.75, p=0.011). 


\section{Relationship between anaemia and clinical events}

The proportion of patients who had any anaemia at diagnosis of a clinical event (combining AIDS, non-AIDS and deaths) was similar when comparing DC and VS arms; 25 of the 55 patients $(45.5 \%)$ in the DC arm who had haemoglobin measured within 28 days of the combined clinical event were anaemic compared to 24 of 47 patients (51.1\%) in the VS arm, $\mathrm{p}=0.57$. There were no significant differences between the DC and VS arms in the proportion of patients with anaemia at 3,6,9 and 12 months prior to the combined clinical event ( $p>0.05$, all comparisons).

Table 3 shows the crude incidence rates of death, AIDS and non AIDS stratified by whether the patient was anaemic at randomization, and using current anaemia status. Anaemia was defined as haemoglobin $\unlhd 4 \mathrm{mg} / \mathrm{dl}$ for male and $\unlhd 2 \mathrm{mg} / \mathrm{dl}$ for female as there was insufficient follow-up among those with severe anaemia ( $\$ 8 \mathrm{mg} / \mathrm{dl}$ for either gender) to include this as a separate category. The incidence of non-AIDS events in patients with or without anaemia during follow-up was 3.37 (95\% CI 2.50-4.25) and 1.13 (95\% CI 0.801.46) per 100 person-years of follow-up (PYFU) respectively. Figure 2 shows the unadjusted and adjusted incidence rate ratios. Current anaemia was a much stronger predictor of any of the clinical events than anaemia at randomisation. For example, compared to non-anaemic patients, those who were currently anaemic had a significantly higher incidence of death (IRR 2.19; 95\% CI 1.23-3.87, $\mathrm{p}=0.0073$ ), AIDS (IRR 2.31; 95\% CI 1.34-3.98, $\mathrm{p}=0.0027$ ) and non-AIDS events (IRR 2.98; 95\% CI 2.01-4.40, $\mathrm{p}<0.0001$ ). Of note, current anaemia was associated with CVD (59 events, adjusted IRR $1.83,95 \%$ CI $1.08-3.13, \mathrm{p}=0.026$ ) and malignancies ( 38 events, adjusted IRR $3.42,95 \%$ CI $1.73-6.77$, $\mathrm{p}=0.0004$ ), the most commonly occurring non-AIDS events.

The association between anaemia status and clinical events became weaker with increasing time since measurement. For example, anaemia status carried forward for up to 6 months (ie not updated until 6 months even if a more recent value was measured) remained predictive of all non-AIDS events (adjusted IRR 1.78; 95\% CI 1.19-2.26, $\mathrm{p}=0.0052$ ), whereas when that time period was extended to 12 months, the relationship between anaemia and nonAIDS events was considerably weaker and not statistically significant (adjusted IRR 1.39; 95\% CI 0.92-2.09, p=0.11). Similar results were seen for death; anaemia status carried forward for up to 6 months remained predictive of death (adjusted IRR 1.77; 95\% CI 1.01$3.09, \mathrm{p}=0.045$ ) but not when that time period was extended to 12 months (adjusted IRR 1.48 ; $95 \%$ CI $0.83-2.63, \mathrm{p}=0.18$ ).

\section{Discussion}

This study from the INSIGHT SMART study group demonstrated that interruption of cART was associated with an increased risk of new or worsening anaemia and that patients who developed anaemia during follow-up had an increased incidence of death, AIDS and non AIDS events, including malignancies and cardiovascular disease, possibly due to deteriorating health and/or subclinical disease(27).

There are a number of potential explanations for our finding that patients who interrupted treatment were more likely to experience new or worsening anaemia. Interrupting treatment in SMART was associated with a decrease in CD4 counts, increased viral replication and an increased risk of clinical events(23). Patients in both the DC and VS arms had similar haemoglobin levels in the months prior to any clinical event, supporting the hypothesis that anaemia was associated with subclinical disease and deteriorating health equally in both arms of the trial, as seen in HIV-negative persons(28-30). In addition, when we increasingly lagged (ie carried forward values that were measured at least a certain period before, rather than using more recent values) the last haemoglobin measurement, the relationship between 
anaemia status and clinical events became weaker. This suggests that haemoglobin levels and development of anaemia in response to subclinical disease tends to generally appear over time in the period prior to diagnosis and that anaemia was a useful short-term marker of clinical disease progression.

An alternative explanation for our findings is that chronic immune activation is associated with changes in haemoglobin. The role of chronic immune activation in HIV disease progression has been raised before $(31 ; 32)$, and previous research from the SMART group has shown that inflammatory markers, such as IL-6 and D-Dimer were associated with interruption of therapy, death and opportunistic disease (33;34). The inflammatory marker differences in SMART were observed within the first few months of randomization(34), whereas in the present analysis, changes in haemoglobin and differences between the randomization arms in the proportion with anaemia appeared more slowly. If anaemia is due to chronic immune activation, it may be that haematologic deterioration takes place only after many months. Although the similar level of anaemia at clinical events in the DC and VS arms supports the hypothesis of anaemia due to subclinical disease and deteriorating health, it is likely there are multiple inter-related and complex pathways that may lead to anaemia in HIV-infected persons.

A number of previous studies have demonstrated that risk of death and AIDS is increased in persons with anaemia or decreased haemoglobin, and a number of studies have developed risk scores to predict disease progression (AIDS or death) which incorporate anaemia $(4 ; 6 ; 7 ; 21-23 ; 35 ; 36)$. The present study benefits from including patients enrolled in a randomized clinical trial and includes a diverse population based on gender, geographic location, race and risk group. There are few previous studies which have reported the relationship between anaemia and non-AIDS events in HIV-infected persons. There is increasing evidence that many so-called non-AIDS events are associated with HIV and occur with increasing frequency with advancing immunodeficiency, including non-AIDS malignancies, liver-related events, and renal disease(37-43), although there is conflicting evidence for cardiovascular disease $(13 ; 44 ; 45)$. This analysis found a consistent relationship between current anaemia status and non-AIDS defining malignancies and CVD, but there were insufficient events to investigate renal $(n=6)$ or liver-related disease $(n=5)$. EuroSIDA, a large observational cohort study, found that development of anaemia was associated with an increased risk of fatal and non-fatal non-AIDS events, the size of the increased risk was similar to that for AIDS events(13). In non-HIV infected persons, anaemia is associated with a range of underlying chronic illnesses associated with increased mortality, such as cardiovascular disease, renal disease, malignancies and liver-related disease(12;46-48), all of which contribute towards non-AIDS events in the SMART study. Anaemia was associated with CVD in this analysis. Chronic anaemia may lead to increased cardiac output, ventricular dilation and left ventricular hypertrophy(49;50), or anaemia may be an underlying risk factor for myocardial ischaemia(30). We also found a strong relationship between being currently anaemic and the development of a non-AIDS associated malignancy. It is possible that the malignancy has infiltrated the bone marrow prior to the diagnosis of the malignancy, or that the patient has a haematological condition that causes both the anaemia and the malignancy $(51)$.

Anemia in HIV-infected patients has a number of clinical implications. Anemia can result in increased fatigue and impaired energy, physical functioning, and overall quality of life, as well as decreased survival( $1 ; 52)$. Management of anemia requires clinical and laboratory evaluation to discover the etiology if it can be identified. Potential causes that should be identified if present and corrected if possible include (among others) blood loss, infiltration of the marrow by neoplasm or infection, hypogonadism, use of myelosuppressive medications, and nutritional deficiencies (e.g., iron, B12 or folate(52)). HAART use may 
result in improvement of existing anemia. If correctable causes of anemia have been ruled out and the hemoglobin level remains low, erythropoietin alfa therapy may be beneficial(53).

There are several issues to be considered in interpreting our results. The observed changes in haemoglobin were in patients randomized to stop treatment which implies that the increased risk of anaemia among those who interrupted ARVs was unlikely to be due to differences in comorbid behaviors (alcohol, poor nutrition) or disease unrelated to HIV infection. A significant proportion of the patients included in this analysis were young female and therefore likely menstruating. We have repeated all analyses separately for men and women and there was no evidence that results differed by gender (data not shown, all $p>0.25$ test for interaction). We used a simple classification for anaemia based on previous work $(8 ; 25)$; the definition of anaemia differs in other studies(54), but a sensitivity analysis using a more specific definition showed similar results. The number of patients developing severe anaemia were too small to allow us to investigate whether severe anaemia had a different relationship with clinical events compared to moderate anaemia. We chose to consider anaemia as a categorical variable. We have also looked at analyses investigating the change over time in haemoglobin (both as a continuous variable and as the proportion of patients with, for example, $>1 \mathrm{mg} / \mathrm{dl}$ decline in haemolgobin per year) and factors associated with this change, with highly consistent results (data not shown). Further information on anaemia, which may help in the interpretation of our data, such as mean corpuscular volume, reticulocyte count, ferratin or Vitamin B12 levels, were not available in this study, nor was information on treatment of anaemia, such as erythropoietin.

To conclude, patients in SMART who interrupted cART had a higher risk of new or worsening anaemia. Patients with anaemia had a higher incidence of AIDS, non-AIDS defining events or deaths; whether this relationship is causal or a consequence of the disease is not clear but suggests that anaemia, or drop in haemoglobin, might be of use as a preclinical marker of disease. From a clinical perspective, our results provide further evidence of the detrimental effects of interruption of ARVs. They also emphasize that close attention should be paid to haemoglobin and anaemia in both patients on and off ARVs as low and decreasing levels are associated with increased likelihood of a wide spectrum of clinical disease. Further research is warranted to further understand the occurrence of anaemia, its consequences and underlying pathological mechanisms.

\title{
Acknowledgments
}

We would like to acknowledge the SMART participants, the SMART study team (see N Engl J Med, 2006:355:2294-2295 for list of investigators), and the INSIGHT Executive Committee.

Funding

Support provided by: NIAID, NIH grants U01AI042170, U01A1068641 and U01AI46362.

\section{Strategies for Management of Antiretroviral Therapy (SMART) Study Group}

\author{
Investigators in the SMART Study Group
}

SMART was initiated by the Terry Beirn Community Programs for Clinical Research on AIDS (CPCRA) and implemented in collaboration with international coordinating centers in Copenhagen (Copenhagen HIV Programme), London (Medical Research Council, Clinical Trials Unit), Sydney (National Centre in HIV Epidemiology and Clinical Research) and Washington (CPCRA). Participating staff are listed below. 
Copenhagen International Coordinating Center: JD Lundgren, KB Jensen, DC Gey, L Borup, M Pearson, PO Jansson, BG Jensen, J Tverland, H Juncker-Benzon, Z Fox, AN Phillips.

London International Coordinating Center: JH Darbyshire, AG Babiker, AJ Palfreeman, SL Fleck, W Dodds, E King, B Cordwell, F van Hooff, Y Collaco-Moraes.

Sydney International Coordinating Center: DA Cooper, S Emery, FM Drummond, SA Connor, CS Satchell, S Gunn, S Oka, MA Delfino, K Merlin, C McGinley.

Washington International Coordinating Center: F Gordin, E Finley, D Dietz, C Chesson, M Vjecha, B Standridge.

INSIGHT Network Coordinating Center: JD Neaton, G Bartsch, A DuChene, M George, B Grund, M Harrison, E Krum, G Larson, C Miller, R Nelson, J Neuhaus, MP Roediger, T Schultz.

ECG Reading Center: R Prineas, C Campbell, Z-M Zhang.

Endpoint Review Committee: G Perez (co-chair), A Lifson (co-chair), D Duprez, J Hoy, C Lahart, D Perlman, R Price, R Prineas, F Rhame, J Sampson, J Worley.

NIAID Data and Safety Monitoring Board: M Rein (chair), R DerSimonian (executive secretary), BA Brody, ES Daar, NN Dubler, TR Fleming, DJ Freeman, JP Kahn, KM Kim, G Medoff, JF Modlin, R Moellering Jr, BE Murray, B Pick, ML Robb, DO Scharfstein, J Sugarman, A Tsiatis, C Tuazon, L Zoloth.

NIH, NIAID: K Klingman, S Lehrman.

SMART Clinical Site Investigators by Country (SMART enrollment)

Argentina (147): J Lazovski, WH Belloso, MH Losso, JA Benetucci, S Aquilia, V Bittar, EP Bogdanowicz, PE Cahn, AD Casiró, I Cassetti, JM Contarelli, JA Corral, A Crinejo, L Daciuk, DO David, G Guaragna, MT Ishida, A Krolewiecki, HE Laplume, MB Lasala, L Lourtau, SH Lupo, A Maranzana, F Masciottra, M Michaan, L Ruggieri, E Salazar, M Sánchez, C Somenzini.

Australia (170): JF Hoy, GD Rogers, AM Allworth, JStC Anderson, J Armishaw, K Barnes, A Carr, A Chiam, JCP Chuah, MC Curry, RL Dever, WA Donohue, NC Doong, DE Dwyer, J Dyer, B Eu, VW Ferguson, MAH French, RJ Garsia, J Gold, JH Hudson, S Jeganathan, P Konecny, J Leung, CL McCormack, M McMurchie, N Medland, RJ Moore, MB Moussa, D Orth, M Piper, T Read, JJ Roney, N Roth, DR Shaw, J Silvers, DJ Smith, AC Street, RJ Vale, NA Wendt, H Wood, DW Youds, J Zillman.

Austria (16): A Rieger, V Tozeau, A Aichelburg, N Vetter.

Belgium (95): N Clumeck, S Dewit, A de Roo, K Kabeya, P Leonard, L Lynen, M Moutschen, E O'Doherty.

Brazil (292): LC Pereira Jr, TNL Souza, M Schechter, R Zajdenverg, MMTB Almeida, F Araujo, F Bahia, C Brites, MM Caseiro, J Casseb, A Etzel, GG Falco, ECJ Filho, SR Flint, CR Gonzales, JVR Madruga, LN Passos, T Reuter, LC Sidi, ALC Toscano.

Canada (102): D Zarowny, E Cherban, J Cohen, B Conway, C Dufour, M Ellis, A Foster, D Haase, H Haldane, M Houde, C Kato, M Klein, B Lessard, A Martel, C Martel, N 
McFarland, E Paradis, A Piche, R Sandre, W Schlech, S Schmidt, F Smaill, B Thompson, S Trottier, S Vezina, S Walmsley.

Chile (49): MJ Wolff Reyes, R Northland.

Denmark (19): L Ostergaard, C Pedersen, H Nielsen, L Hergens, IR Loftheim, KB Jensen.

Estonia (5): M Raukas, K Zilmer.

Finland (21): J Justinen, M Ristola.

France (272): PM Girard, R Landman, S Abel, S Abgrall, K Amat, L Auperin, R Barruet, A Benalycherif, N Benammar, M Bensalem, M Bentata, JM Besnier, M Blanc, O Bouchaud, A Cabié, P Chavannet, JM Chennebault, S Dargere, $\mathrm{X}$ de la Tribonniere, T Debord, N Decaux, J Delgado, M Dupon, J Durant, V Frixon-Marin, C Genet, L Gérard, J Gilquin, B Hoen, V Jeantils, H Kouadio, P Leclercq, CP Michon, P Nau, J Pacanowski, C Piketty, I PoizotMartin, I Raymond, D Salmon, JL Schmit, MA Serini, A Simon, S Tassi, F Touam, R Verdon, P Weinbreck, L Weiss, Y Yazdanpanah, P Yeni.

Germany (215): G Fätkenheuer, S Staszewski, F Bergmann, S Bitsch, JR Bogner, N Brockmeyer, S Esser, FD Goebel, M Hartmann, H Klinker, C Lehmann, T Lennemann, A Plettenberg, A Potthof, J Rockstroh, B Ross, A Stoehr, JC Wasmuth, K Wiedemeyer, R Winzer.

Greece (95): A Hatzakis, G Touloumi, A Antoniadou, GL Daikos, A Dimitrakaki, P Gargalianos-Kakolyris, A Karafoulidou, A Katsambas, O Katsarou, AN Kontos, T Kordossis, MK Lazanas, P Panagopoulos, G Panos, V Paparizos, V Papastamopoulos, G Petrikkos, A Skoutelis, N Tsogas, G Xylomenos.

Ireland (2): CJ Bergin, B Mooka.

Israel (13): S Pollack, MG Mamorksy, N Agmon-Levin, R Karplus, E Kedem, S Maayan, E Shahar, Z Sthoeger, D Turner, I Yust.

Italy (88): G Tambussi, V Rusconi, C Abeli, M Bechi, A Biglino, L Butini, G Carosi, S Casari, A Corpolongo, M De Gioanni, M Di Pietro, G D’Offizi, R Esposito, F Mazzotta, M Montroni, G Nardini, S Nozza, T Quirino, E Raise.

Japan (15): M Honda, M Ishisaka.

Lithuania (4): S Caplinskas, V Uzdaviniene.

Luxembourg (3): JC Schmit, T Staub.

Morocco (42): H Himmich, K Marhoum El Filali.

New Zealand (7): GD Mills, T Blackmore, JA Masters, J Morgan, A Pithie.

Norway (17): J Brunn, V Ormasssen.

Peru (57): A La Rosa, O Guerra, M Espichan, L Gutierrez, F Mendo, R Salazar.

Poland (54): B Knytz, A Horban, E Bakowska, M Beniowski, J Gasiorowski, J Kwiatkowski. 
Portugal (73): F Antunes, RS Castro, M Doroana, A Horta, K Mansinho, AC Miranda, IV Pinto, E Valadas, J Vera.

Russia (17): A Rakhmanova, E Vinogradova, A Yakovlev, N Zakharova.

South Africa (26): R Wood, C Orrel.

Spain (100): J Gatell, JA Arnaiz, R Carrillo, B Clotet, D Dalmau, A González, Q Jordano, A Jou, H Knobel, M Larrousse, R Mata, JS Moreno, E Oretaga, JN Pena, F Pulido, R Rubio, J Sanz, P Viciana.

Switzerland (91): B Hirschel, R Spycher, M Battegay, E Bernasconi, S Bottone, M Cavassini, A Christen, C Franc, HJ Furrer, A Gayet-Ageron, D Genné, S Hochstrasser, L Magenta, C Moens, N Müller, R Nüesch.

Thailand (159): P Phanuphak, K Ruxrungtham, W Pumpradit, P Chetchotisakd, S Dangthongdee, S Kiertiburanakul, V Klinbuayaem, P Mootsikapun, S Nonenoy, B Piyavong, W Prasithsirikul, P Raksakulkarn.

United Kingdom (214): BG Gazzard, JG Ainsworth, J Anderson, BJ Angus, TJ Barber, MG Brook, DR Chadwick, M Chikohora, DR Churchill, D Cornforth, PJ Easterbrook, PA Fox, R Fox, PA Gomez, MM Gompels, GM Harris, S Herman, AGA Jackson, SPR Jebakumar, MA Johnson, GR Kinghorn, KA Kuldanek, N Larbalestier, C Leen, M Lumsden, T Maher, J Mantell, R Maw, S McKernan, L McLean, S Morris, L Muromba, CM Orkin, AJ Palfreeman, BS Peters, TEA Peto, SD Portsmouth, S Rajamanoharan, A Ronan, A Schwenk, MA Slinn, CJ Stroud, RC Thomas, MH Wansbrough-Jones, HJ Whiles, E Williams, IG Williams, M Youle.

United States (2989): DI Abrams, EA Acosta, S Adams, A Adamski, L Andrews, D Antoniskis, DR Aragon, R Arduino, R Artz, J Bailowitz, BJ Barnett, C Baroni, M Barron, JD Baxter, D Beers, M Beilke, D Bemenderfer, A Bernard, CL Besch, MT Bessesen, JT Bethel, S Blue, JD Blum, S Boarden, RK Bolan, JB Borgman, I Brar, BK Braxton, UF Bredeek, R Brennan, DE Britt, J Brockelman, S Brown, V Bruzzese, D Bulgin-Coleman, DE Bullock, V Cafaro, B Campbell, S Caras, J Carroll, KK Casey, F Chiang, G Childress, RB Cindrich, C Clark, M Climo, C Cohen, J Coley, DV Condoluci, R Contreras, J Corser, J Cozzolino, LR Crane, L Daley, D Dandridge, V D’Antuono, JG Darcourt Rizo Patron, JA DeHovitz, E DeJesus, J DesJardin, M Diaz-Linares, C Dietrich, P Dodson, E Dolce, K Elliott, D Erickson, M Estes, LL Faber, J Falbo, MJ Farrough, CF Farthing, P FerrellGonzalez, H Flynn, C Frank, M Frank, KF Freeman, N French, G Friedland, N Fujita, L Gahagan, K Genther, I Gilson, MB Goetz, E Goodwin, F Graziano, CK Guity, P Gulick, ER Gunderson, CM Hale, K Hannah, H Henderson, K Hennessey, WK Henry, DT Higgins, SL Hodder, HW Horowitz, M Howe-Pittman, J Hubbard, R Hudson, H Hunter, C Hutelmyer, MT Insignares, L Jackson, L Jenny, M John, DL Johnson, G Johnson, J Johnson, L Johnson, J Kaatz, J Kaczmarski, S Kagan, C Kantor, T Kempner, K Kieckhaus, N Kimmel, BM Klaus, N Klimas, JR Koeppe, J Koirala, J Kopka, JR Kostman, MJ Kozal, A Kumar, A Labriola, H Lampiris, C Lamprecht, KM Lattanzi, J Lee, J Leggett, C Long, A Loquere, K Loveless, CJ Lucasti, R Luskin-Hawk, M MacVeigh, LH Makohon, S Mannheimer, NP Markowitz, C Marks, N Martinez, C Martorell, E McFeaters, B McGee, DM McIntyre, J McKee, E McManus, LG Melecio, D Melton, S Mercado, E Merrifield, JA Mieras, M Mogyoros, FM Moran, K Murphy, D Mushatt, S Mutic, I Nadeem, R Nahass, D Nixon, S O’Brien, A Ognjan, M O'Hearn, K O'Keefe, PC Okhuysen, E Oldfield, D Olson, R Orenstein, R Ortiz, J Osterberger, W Owen, F Parpart, V Pastore-Lange, S Paul, A Pavlatos, DD Pearce, R Pelz, G Perez, S Peterson, G Pierone Jr, D Pitrak, SL Powers, HC Pujet, JW Raaum, J Ravishankar, J Reeder, N Regevik, NA Reilly, C Reyelt, J Riddell IV, D Rimland, 
ML Robinson, AE Rodriguez, MC Rodriguez-Barradas, V Rodriguez Derouen, R Roland, C Rosmarin, WL Rossen, JR Rouff, JH Sampson, M Sands, C Savini, S Schrader, MM Schulte, C Scott, R Scott, H Seedhom, M Sension, A Sheble-Hall, A Sheridan, J Shuter, LN Slater, R Slotten, D Slowinski, M Smith, S Snap, C Somboonwit, DM States, M Stewart, G Stringer, J Sullivan, KK Summers, K Swanson, IB Sweeton, S Szabo, EM Tedaldi, EE Telzak, Z Temesgen, D Thomas, MA Thompson, S Thompson, C Ting Hong Bong, C Tobin, J Uy, A Vaccaro, LM Vasco, I Vecino, GK Verlinghieri, F Visnegarwala, BH Wade, V Watson, SE Weis, JA Weise, S Weissman, AM Wilkin, L Williams, JH Witter, L Wojtusic, TJ Wright, V Yeh, B Young, C Zeana, J Zeh.

Uruguay (3): E Savio, M Vacarezza.

\section{Reference List}

1. Volberding PA, Levine AM, Dieterich D, Mildvan D, Mitsuyasu R, Saag M. Anemia in HIV infection: clinical impact and evidence-based management strategies. Clin Infect Dis. 2004 May 15; 38(10):1454-63. [PubMed: 15156485]

2. Sullivan PS, Hanson DL, Chu SY, Jones JL, Ward JW. Epidemiology of anemia in human immunodeficiency virus (HIV)-infected persons: results from the multistate adult and adolescent spectrum of HIV disease surveillance project. Blood. 1998 Jan 1; 91(1):301-8. [PubMed: 9414298]

3. Curkendall SM, Richardson JT, Emons MF, Fisher AE, Everhard F. Incidence of anaemia among HIV-infected patients treated with highly active antiretroviral therapy. HIV Med. 2007 Nov; 8(8): 483-90. [PubMed: 17944680]

4. Zhou J, Kumarasamy N. Predicting short-term disease progression among HIV-infected patients in Asia and the Pacific region: preliminary results from the TREAT Asia HIV Observational Database (TAHOD). HIV Med. 2005 May; 6(3):216-23. [PubMed: 15876289]

5. Anastos K, Shi Q, French AL, et al. Total lymphocyte count, hemoglobin, and delayed-type hypersensitivity as predictors of death and AIDS illness in HIV-1-infected women receiving highly active antiretroviral therapy. J Acquir Immune Defic Syndr. 2004 Apr 1; 35(4):383-92. [PubMed: 15097155]

6. Harris RJ, Sterne JA, Abgrall S, et al. Prognostic importance of anaemia in HIV type-1-infected patients starting antiretroviral therapy: collaborative analysis of prospective cohort studies. Antivir Ther. 2008; 13(8):959-67. [PubMed: 19195321]

7. Justice AC, McGinnis KA, Skanderson M, et al. Towards a combined prognostic index for survival in HIV infection: the role of 'non-HIV' biomarkers. HIV Med. 2009 Sep 14.

8. Mocroft A, Kirk O, Barton SE, et al. Anaemia is an independent predictive marker for clinical prognosis in HIV-infected patients from across Europe. EuroSIDA study group. AIDS. 1999 May 28; 13(8):943-50. [PubMed: 10371175]

9. Westenbrink BD, de Boer RA, Voors AA, van Gilst WH, van Veldhuisen DJ. Anemia in chronic heart failure: etiology and treatment options. Curr Opin Cardiol. 2008 Mar; 23(2):141-7. [PubMed: 18303527]

10. Blohmer JU, Dunst J, Harrison L, et al. Cancer-related anemia: biological findings, clinical implications and impact on quality of life. Oncology. 2005; 68(Suppl 1):12-21. [PubMed: 15855812]

11. Mitchell JE. Emerging role of anemia in heart failure. Am J Cardiol. 2007 Mar 26; 99(6B):15D20D.

12. Iseki K, Kohagura K. Anemia as a risk factor for chronic kidney disease. Kidney Int Suppl. 2007 Nov.(107):S4-S9. [PubMed: 17943141]

13. Mocroft, A.; Reiss, P.; Gasiorowski, J., et al. Serious Fatal and Non Fatal Non-AIDS Defining Illnesses (non-ADI) in Europe. JAIDS; 16th Conference on Retroviruses and Opportunistic Infections; Montreal, Canada. 2009; 2010. Abstract 707. In press

14. Moh R, Danel C, Sorho S, et al. Haematological changes in adults receiving a zidovudinecontaining HAART regimen in combination with cotrimoxazole in Cote d'Ivoire. Antivir Ther. 2005; 10(5):615-24. [PubMed: 16152755] 
15. Ssali F, Stohr W, Munderi P, et al. Prevalence, incidence and predictors of severe anaemia with zidovudine-containing regimens in African adults with HIV infection within the DART trial. Antivir Ther. 2006; 11(6):741-9. [PubMed: 17310818]

16. Hughes WT, LaFon SW, Scott JD, Masur H. Adverse events associated with trimethoprimsulfamethoxazole and atovaquone during the treatment of AIDS-related Pneumocystis carinii pneumonia. J Infect Dis. 1995 May; 171(5):1295-301. [PubMed: 7751706]

17. Fangman JJ, Scadden DT. Anemia in HIV-infected adults: epidemiology, pathogenesis, and clinical management. Curr Hematol Rep. 2005 Mar; 4(2):95-102. [PubMed: 15720957]

18. McGinniss MH, Macher AM, Rook AH, Alter HJ. Red cell autoantibodies in patients with acquired immune deficiency syndrome. Transfusion. 1986 Sep; 26(5):405-9. [PubMed: 3765030]

19. Rule S, Reed C, Costello C. Fatal haemophagocytic syndromes in HIV-antibody positive patient. Br J Haematol. 1991 Sep.79(1):127. [PubMed: 1911374]

20. Sasadeusz J, Buchanan M, Speed B. Reactive haemophagocytic syndrome in human immunodeficiency virus infection. J Infect. 1990 Jan; 20(1):65-8. [PubMed: 2299185]

21. Moore RD, Forney D. Anemia in HIV-infected patients receiving highly active antiretroviral therapy. J Acquir Immune Defic Syndr. 2002 Jan 1; 29(1):54-7. [PubMed: 11782590]

22. Berhane K, Karim R, Cohen MH, et al. Impact of highly active antiretroviral therapy on anemia and relationship between anemia and survival in a large cohort of HIV-infected women: Women's Interagency HIV Study. J Acquir Immune Defic Syndr. 2004 Oct 1; 37(2):1245-52. [PubMed: 15385731]

23. El-Sadr WM, Lundgren JD, Neaton JD, et al. CD4+ count-guided interruption of antiretroviral treatment. N Engl J Med. 2006 Nov 30; 355(22):2283-96. [PubMed: 17135583]

24. Risk for Opportunistic Disease and Death after Reinitiating Continuous Antiretroviral Therapy in Patients with HIV Previously Receiving Episodic Therapy: A Randomized Trial. Ann Intern Med. 2008 Sep 2; 149(5):289-99. [PubMed: 18765698]

25. Berliner, N. DTAH. Approach to the adult and child with anemia. In: Hoffman, R.; BESSFBCHSL, editors. Hematology basic principles and practice. Second Edition. Churchill Livingstone: 1995. p. 468-83.

26. Neuhaus J, Angus B, Kowalska JD, et al. Risk of all-cause mortality associated with nonfatal AIDS and serious non-AIDS events among adults infected with HIV. AIDS. 2010 Mar 13; 24(5): 697-706. [PubMed: 20177360]

27. Zakai NA, Katz R, Hirsch C, et al. A prospective study of anemia status, hemoglobin concentration, and mortality in an elderly cohort: the Cardiovascular Health Study. Arch Intern Med. 2005 Oct 24; 165(19):2214-20. [PubMed: 16246985]

28. Ma JZ, Ebben J, Xia H, Collins AJ. Hematocrit level and associated mortality in hemodialysis patients. J Am Soc Nephrol. 1999 Mar; 10(3):610-9. [PubMed: 10073612]

29. Nissenson AR, Goodnough LT, Dubois RW. Anemia: not just an innocent bystander? Arch Intern Med. 2003 Jun 23; 163(12):1400-4. [PubMed: 12824088]

30. Sarnak MJ, Tighiouart H, Manjunath G, et al. Anemia as a risk factor for cardiovascular disease in The Atherosclerosis Risk in Communities (ARIC) study. J Am Coll Cardiol. 2002 Jul 3; 40(1):2733. [PubMed: 12103252]

31. Lederman MM, Kalish LA, Asmuth D, Fiebig E, Mileno M, Busch MP. 'Modeling' relationships among HIV-1 replication, immune activation and CD4+ T-cell losses using adjusted correlative analyses. AIDS. 2000 May 26; 14(8):951-8. [PubMed: 10853976]

32. Sodora DL, Silvestri G. Immune activation and AIDS pathogenesis. AIDS. 2008 Feb 19; 22(4): 439-46. [PubMed: 18301056]

33. Rodger AJ, Fox Z, Lundgren JD, et al. Activation and Coagulation Biomarkers Are Independent Predictors of the Development of Opportunistic Disease in Patients with HIV Infection. J Infect Dis. 2009 Sep 15; 200(6):973-83. [PubMed: 19678756]

34. Kuller LH, Tracy R, Belloso W, et al. Inflammatory and coagulation biomarkers and mortality in patients with HIV infection. PLoS Med. 2008 Oct 21.5(10):e203. [PubMed: 18942885]

35. Mocroft A, Ledergerber B, Zilmer K, et al. Short-term clinical disease progression in HIV-1positive patients taking combination antiretroviral therapy: the EuroSIDA risk-score. AIDS. 2007 Sep 12; 21(14):1867-75. [PubMed: 17721094] 
36. Subbaraman R, Devaleenal B, Selvamuthu P, et al. Factors associated with anaemia in HIVinfected individuals in southern India. Int J STD AIDS. 2009 Jul; 20(7):489-92. [PubMed: 19541892]

37. Reekie J, Mocroft A, Engsig F, d'Arminio Monforte A, Wiercinska-Drapalo A, Domingo P, Antunes F, Clumeck N, Kirk O, Lundgren JD. Relationship between current level of immunodeficiency and non-AIDS defining malignancies. Cancer. 2010 In press.

38. Baker JV, Peng G, Rapkin J, et al. CD4+ count and risk of non-AIDS diseases following initial treatment for HIV infection. AIDS. 2008 Apr 23; 22(7):841-8. [PubMed: 18427202]

39. Mocroft A, Soriano V, Rockstroh J, et al. Is there evidence for an increase in the death rate from liver-related disease in patients with HIV? AIDS. 2005 Dec 2; 19(18):2117-25. [PubMed: $16284461]$

40. Monforte A, Abrams D, Pradier C, et al. HIV-induced immunodeficiency and mortality from AIDS-defining and non-AIDS-defining malignancies. AIDS. 2008 Oct 18; 22(16):2143-53. [PubMed: 18832878]

41. Moore RD, Gebo KA, Lucas GM, Keruly JC. Rate of comorbidities not related to HIV infection or AIDS among HIV-infected patients, by CD4 cell count and HAART use status. Clin Infect Dis. 2008 Oct 15; 47(8):1102-4. [PubMed: 18781885]

42. Smith CJ, Olsen CH, Mocroft A, et al. The role of antiretroviral therapy in the incidence of pancreatitis in HIV-positive individuals in the EuroSIDA study. AIDS. 2008 Jan 2; 22(1):47-56. [PubMed: 18090391]

43. Weber R, Sabin CA, Friis-Moller N, et al. Liver-related deaths in persons infected with the human immunodeficiency virus: the D:A:D study. Arch Intern Med. 2006 Aug 14; 166(15):1632-41. [PubMed: 16908797]

44. Lichtenstein KA, Armon C, Buchacz K, et al. Low CD4+ T cell count is a risk factor for cardiovascular disease events in the HIV outpatient study. Clin Infect Dis. 2010 Aug 15; 51(4): 435-47. [PubMed: 20597691]

45. Phillips AN, Carr A, Neuhaus J, et al. Interruption of antiretroviral therapy and risk of cardiovascular disease in persons with HIV-1 infection: exploratory analyses from the SMART trial. Antivir Ther. 2008; 13(2):177-87. [PubMed: 18505169]

46. Astor BC, Coresh J, Heiss G, Pettitt D, Sarnak MJ. Kidney function and anemia as risk factors for coronary heart disease and mortality: the Atherosclerosis Risk in Communities (ARIC) Study. Am Heart J. 2006 Feb; 151(2):492-500. [PubMed: 16442920]

47. Schlichting P, Christensen E, Andersen PK, et al. Prognostic factors in cirrhosis identified by Cox's regression model. Hepatology. 1983 Nov; 3(6):889-95. [PubMed: 6354903]

48. Cella D, Kallich J, McDermott A, Xu X. The longitudinal relationship of hemoglobin, fatigue and quality of life in anemic cancer patients: results from five randomized clinical trials. Ann Oncol. 2004 Jun; 15(6):979-86. [PubMed: 15151958]

49. Varat MA, Adolph RJ, Fowler NO. Cardiovascular effects of anemia. Am Heart J. 1972 Mar; 83(3):415-26. [PubMed: 4551028]

50. Metivier F, Marchais SJ, Guerin AP, Pannier B, London GM. Pathophysiology of anaemia: focus on the heart and blood vessels. Nephrol Dial Transplant. 2000; 15(Suppl 3):14-8. [PubMed: 11032352]

51. Ludwig H, Fritz E. Anemia in cancer patients. Semin Oncol. 1998 Jun; 25(3 Suppl 7):2-6. [PubMed: 9671322]

52. Belperio PS, Rhew DC. Prevalence and outcomes of anemia in individuals with human immunodeficiency virus: a systematic review of the literature. Am J Med. 2004 Apr 5; 116(Suppl 7A):27S-43S. [PubMed: 15050884]

53. Henry DH, Volberding PA, Leitz G. Epoetin alfa for treatment of anemia in HIV-infected patients: past, present, and future. J Acquir Immune Defic Syndr. 2004 Oct 1; 37(2):1221-7. [PubMed: 15385728]

54. Beutler E, Waalen J. The definition of anemia: what is the lower limit of normal of the blood hemoglobin concentration? Blood. 2006 Mar 1; 107(5):1747-50. [PubMed: 16189263] 


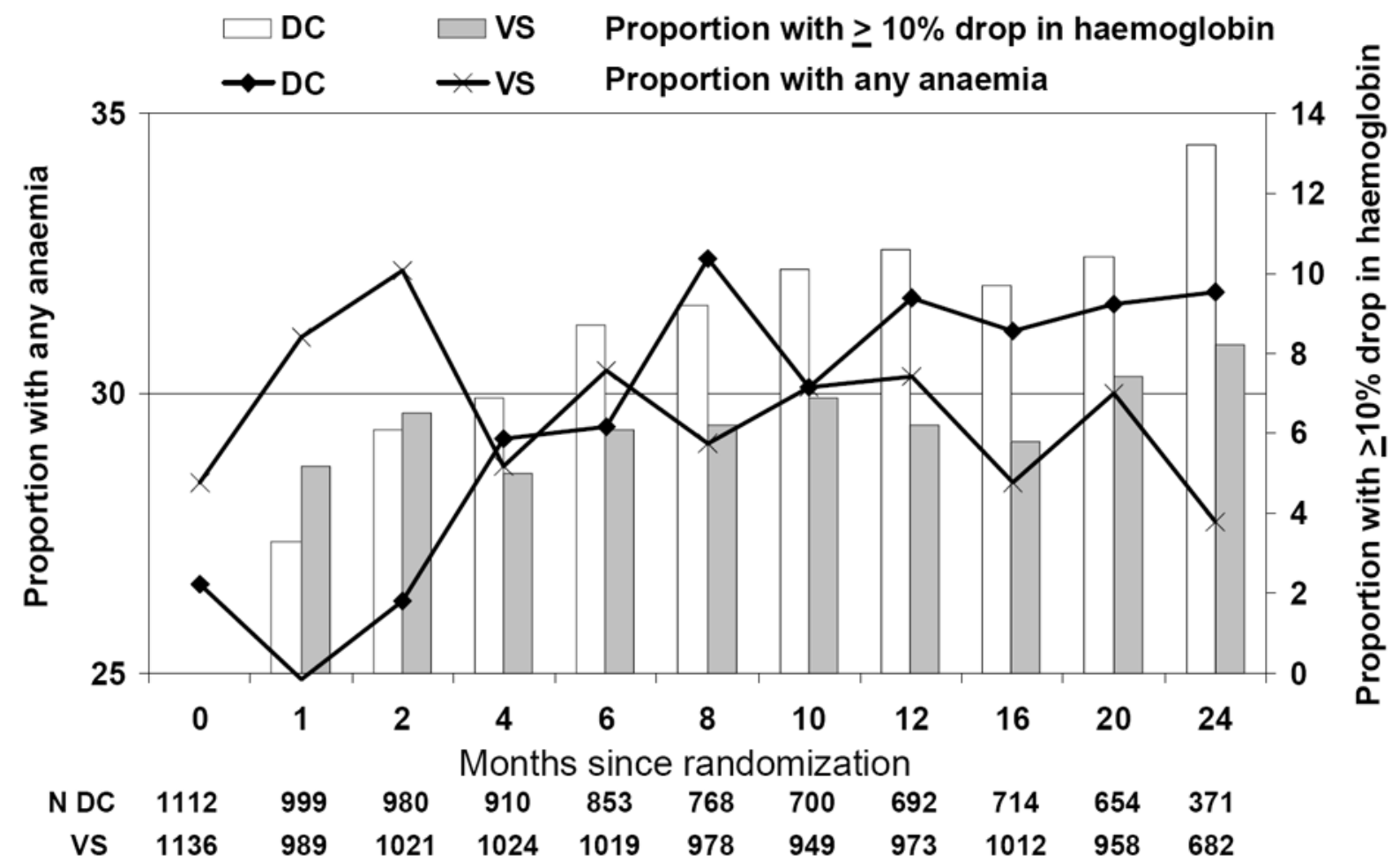

Figure 1. Haemoglobin and anaemia after randomisation in SMART

Patients in DC arm were censored at restarting treatment. Anaemia defined as haemoglobin $\leq 4 \mathrm{mg} / \mathrm{dl}$ (Male) / $\leq 2 \mathrm{mg} / \mathrm{dl}$ (Female) 
No anaemia (reference group)

Anaemic at randomization, unadjusted

Anaemic at randomization, adjusted ${ }^{1}$

Currently anaemic, adjusted ${ }^{2}$

No anaemia (reference group)

Anaemic at randomization, unadjusted

Anaemic at randomization, adjusted ${ }^{1}$

Currently anaemic, adjusted ${ }^{3}$

No anaemia (reference group)

Anaemic at randomization, unadjusted

Anaemic at randomization, adjusted 1

Currently anaemic, adjusted ${ }^{4}$

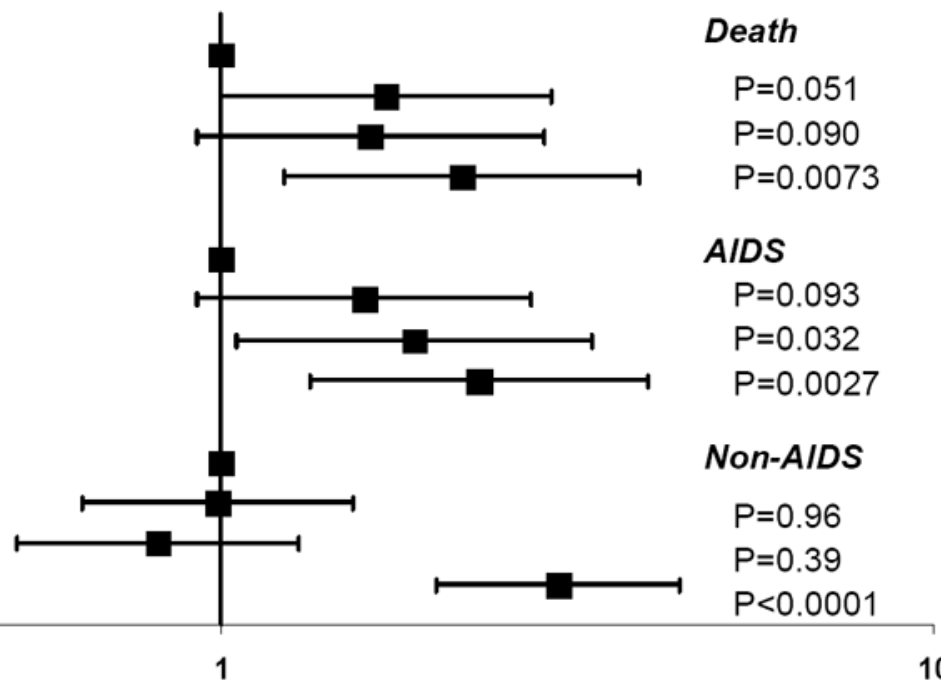

0.1

Incidence rate ratio $(95 \% \mathrm{Cl})$

Figure 2. Incidence rate ratio of death, AIDS or serious non-AIDS events

Anaemia defined as haemoglobin $\leq 4 \mathrm{mg} / \mathrm{dl}$ (Male) and $\unlhd 2 \mathrm{mg} / \mathrm{dl}$ (Female)

See Table 3 for number of events. All adjusted models are adjusted for gender, race, region, HIV exposure group, hepatitis B and C status, age, CD4 nadir, treatment at randomisation, DC versus VS arm, antiretroviral naïve at randomisation and date of randomisation. ${ }^{1}$ Also adjusted for prior AIDS or non-AIDS at randomisation, CD4 and viral load at randomisation. ${ }^{2}$ Also adjusted for development of AIDS or non-AIDS during follow-up, current CD4 and current viral load. ${ }^{3}$ Also adjusted for of non-AIDS during follow-up, AIDS at randomisation, current CD4 and current viral load. ${ }^{4}$ Also adjusted for development of AIDS during follow-up, current CD4, current viral load and non-AIDS at randomisation 


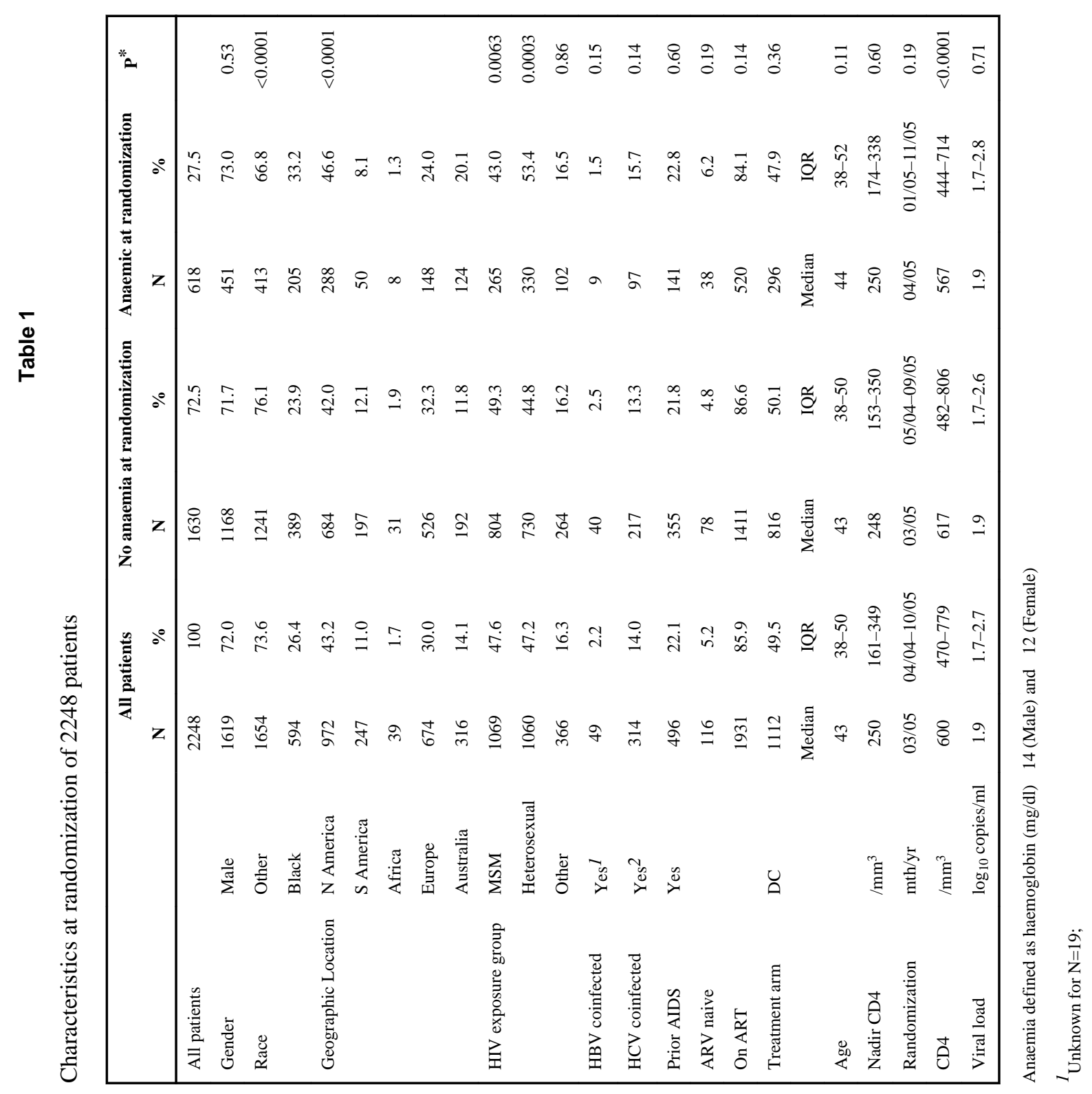




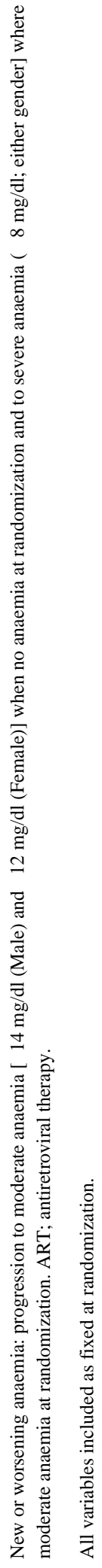

Antivir Ther. Author manuscript; available in PMC 2014 February 03. 
